A Journal of Culture, English Language, Teaching \& Literature ISSN 1414-3320 (Print), ISSN 2502-4914 (Online)

$$
\text { Vol. } 18 \text { No.1; July } 2018
$$

Copyright (C) Soegijapranata Catholic University, Indonesia

The Implementation of Herringbone Technique in Reading Comprehension at Second Semester of Non-English Department

\title{
Hidayatur Rohmah
}

Education of English Language and Literature, Post Graduate Program, Surabaya State University, Surabaya, Indonesia email: hidayaturrohmah@unwaha.ac.id; hidajauhar@gmail.com 


\title{
The Implementation of Herringbone Technique in Reading Comprehension at Second Semester of Non-English Department
}

\author{
Hidayatur Rohmah
}

hidayaturrohmah@unwaha.ac.id; hidajauhar@gmail.com

Education of English Language and Literature, Post Graduate

Program, Surabaya State University, Indonesia

\begin{abstract}
Herringbone technique is the technique to help students find important information and main idea in a text by seeking the answer of six comprehension questions on a diagram. This study is intended to know how the lecturer's implement herringbone technique to the students' reading comprehension, especially detail information and main idea. The research was done at STAI Bahrul 'Ulum Tambakberas. The subject of the study was the second semester of PAI-A students consisting 33 students. The study is descriptive qualitative conducted in four meetings. The researcher applied several techniques including observation, field notes, interview, questionnaire, and students' test. To analyze the lecture's implementation, data condensation which are selecting, focusing, simplifying, abstracting and transforming all the data found. Then data display means compressed the information, and the last was conclusion drawing. In analyzing the test, the researcher used holistic scoring scale adapted from Brown. And diagram used to analyze the students' respond toward the implementation. The research finding shows that the implementation of herringbone technique is conducted into three phases; (1) pre-reading phase, which focussed on background knowledge and brainstorm, (2) whilstreading, which consist on reading activity, fill and discuss the diagram, and (3) post-reading which mean to check the students' understanding. In conclusion, the use of herringbone technique in teaching reading comprehension requires the lecture to do specific activities of teaching and learning process in accordance with the stages of herringbone technique. The student's responses result to the herringbone questions and the number of main ideas during teaching learning process increased from first until fourth meeting. The students' responded toward the implementation of herringbone technique was very good, gave
\end{abstract}


Rohmah, H., The Implementation of Herringbone Technique in Reading

possitive effect and helped them more easily in understanding the text.

Key words: reading, reading comprehension, herringbone technique, main idea.

Abstrak: Teknik herringbone adalah teknik untuk membantu peserta didik menemukan informasi penting dan ide pokok teks dengan melihat enam pertanyaan pemahaman pada diagram, penyelidikan ini berniat unuk mengetahui bagaimana dosen menerapkan teknik herringbone pada mahasiswa dalam pemahaman membaca menggunakan teks naratif, terutama pada informasi lengkap dan ide pokok. Penelitian ini dilakukan di STAI-BU Tambakberas. Pesertanya adalah mahasiswa semeser2 PAI-A yang terdiri dari 33 mahasiswa. Jenis penelitian deskriptif kualitatif digunakan. Penulis menggunakan beberapa teknik seperti catatan lapangan, observasi, interview, pertanyaan, dan tes. Untuk menganalisa penerapan herringbone menggunakan data kondensasi yakni menyeleksi, memfokuskan, menyederhanakan, meringkas, dan mentransfer semua data yang ditemukan. Lalu data display dilakukan untuk meringkas informasi. Dan yang terakhir menarik kesimpulan. Dalam menganalisa tes, peneliti menggunakan skala nilai secara keseluruhan diadaptasi dari Brown.Untuk respon siswa menggunakan diagram. Temuan-temuan menunjukkan bahwa implementasi teknik herringbone dilaksanakan dalam tiga tahap;(1) sebelum tahap membaca, yakni fokus pada latar belakang pengetahuan, mengungkapkan pendapat,(2)selagi membaca,yang terdiri dari kegiatan membaca, mengisi dan mendiskusikan diagram herringbone, dan (3) akhir membaca yang dimaksudkan untuk mengecek pemahaman siswa. Pada akhirnya, penerapan herringbbone technique dalam mengajar mengajar pemahaman membaca pada tekks naratif mengharuskan dosen untuk melakukan aktifitas belajar mengajar yang spesifik sesuai dengan tahap teknik herringbone. Hasil jawaban siswa pada peranyaanpertanyaan dan ide pokok di teknik herringbone selama proses belajar mengajar meningkat dari pertemuan pertama sampai pertemuan ke empat. Respon siswa terhadap penerapah teknik herringbone juga sangat bagus, memberikan efek positif dan membantu siswa lebih mudah mengerti dalam memahami teks.

Kata kunci: membaca, pemahaman membaca, teknik herringbone, ide pokok. 


\section{INTRODUCTION}

Reading is one of the ways to get information. Reading becomes an important part in our life, because sometimes to get the information the people will read. Reading which constitutes one of English language skills is also beneficial in learning English. When students read text, for instance, the text that students read can be useful to support their writing skill and enrich them with vocabulary, grammar and so on.

Furthermore, Richard (1996, p.164) affirms that reading comprehension activities may address different levels of comprehension, including literal comprehension (understanding meanings stated explicitly in a text), inferential comprehension (drawing conclusions and making predictions based on information in the text), and evaluation (making judgment about the content of a text based on personal or other values). Reading comprehension gives the big contribution to students to perform their communication skill better. In their daily life, students are always related to the written or printed words, for instance: text books, magazines, newspapers, announcements, letters, even advertisement. By reaching good reading comprehension, the students can catch the information given by the writer well.

For non-English department students, reading does not merely mean to understand the meaning of words or recognize new vocabulary of English but comprehend the content of written information or message explicitly and implicitly as well. The reader requires good comprehension to obtain message or information from the materials he or she reads. The next problem the students can not comprehend the text well. Therefore, reading skill should be taught seriously in the classroom in order to make the students understand the text.

Herringbone technique tries to accommodate six comprehension questions (who, what, when, where, how, and why) to get the information of the text. When the students answer the six questions above, students also write the main idea across the backbone of the fish diagram. The information can lead the readers to get the topic of the text that they read. This is one of the technique that influence students in understanding and comprehending the text.

This study tries to explain in detail about efforts or steps when implementing Herringbone technique to make the six questions in Herringbone technique: who, what, when, where, why, and how be integratedly chained. This study also describe the students' results in reading 
Rohmah, H., The Implementation of Herringbone Technique in Reading

comprehension through the implementation of Herringbone technique, and about the students' respond to the implementation of the Herringbone technique in reading comprehension class.

\section{REVIEW OF LITERATURE ON READING}

Nuttal (1996, p. 4) states that reading is a perceptive process in which people look at and interact with the text, to understand, interpret and attain meaning to the written symbols in the text. If someone rread the other symbols could be number or other kinds of meaningful pattern, such as the arrangement of an offensive football team, but it does not mean reading.

Reading is also regarded as a skill that is interpreting codes into ideas. According to Nunan (2003, p.4), reading is viewed as a process of decoding written symbols, working from smaller units (individual letters) to larger ones (words, clauses and sentences). In other words, the use of techniques are to decode written forms in order to arrive at meaning. Based on the theory above, the researcher assumes that reading is an activity involving the process of interaction between the reader and the text in which the content of the text is selected to get an understanding of the message written beyond it.

\section{A. Reading comprehension}

Smith (2003, p. 19), states that comprehension is building understanding, both of a particular text and the more global concepts around which it is built. It is an active and demanding process, especially when students are reading to learn new and difficult concepts. Furthermore he also defines that readingcomprehension is a process that begins with word recognition. It does not end, however, until students derived meaning from the ideas both stated implied in the text and have been able to evaluate and respond to these ideas.

Richard (2001) defines that reading comprehension is a process of using syntactic and semantic information found in printed text to reconstruct in the reeader's mind. According to Snow (2002), reading comprehension as the process of simultaneously extracting and constructing meaning through interaction and involvement with written language. From the theories presented above, it can be inferred that reading comprehension is an ability to understand what he/she reads by involving his experience and knowledge. The differences of experiences and background knowledge brought to the text can 
cause variationin comprehension. Then, the comprehension process itself can be referred to what good readers do when read.

\section{B. The Herringbone technique}

Deegan (2006, p.102) states that Herringbone technique develops comprehension of the main idea by plotting who, what, when, where, why, and how question on a visual diagram of a fish skeleton. Using the answer to the WH questions, the students writes the main idea across the backbone of the fish diagram. According to Tierney, Readence, \& Dishner (1980) say that Herringbone technique is a structured outlining procedure designed to help students organize important information in a text chapter. So, Herringbone technique can help students to understand the information of the text.

\section{Figure 1: \\ Herringbone diagram}

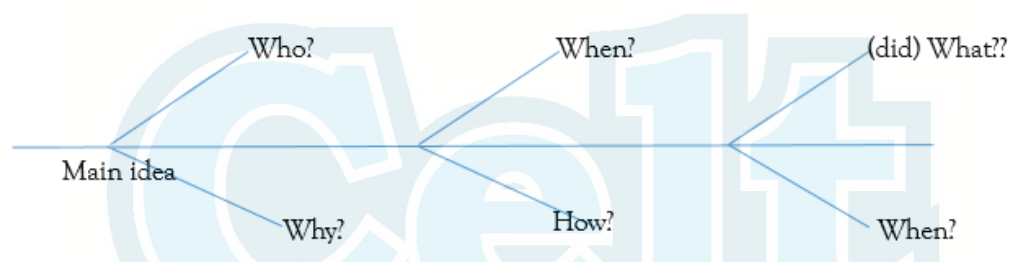

In uns researcil, nemmyoune tecinnque neips me stuuents unuerstand the connections between supporting details to identify a main idea. The herringbone is a useful graphic organizer for students to organize information.

The advantages of Herringbone technique according to Bouchard (2005, p. 54) is being able to answer and understsand the questions who, what, when, why, where, and how can greatly aid ELLs when reading and comprehending text. This strategy also shows the relationship of the details to the main idea, which is often a troublesome comcept for ELLs. On the other side, there are some advantages of Herringbone technique, they are: (1) the students will be more active in the class especially in reading. When they do the steps of herringbone technique in reading, they will have activities that make them active in the class. (2) herringbone technique also makes the students enthusiastic in reading a text, because they just focus on the simple question. (3) in discussion process the students can share the information about the text that they have already red. (4) he activities in reading make the students fresh and out of boring reading. And (5) herringbone technique activities can makes the students are easier to find the main idea of the text. 
Rohmah, H., The Implementation of Herringbone Technique in Reading

\section{RESEARCH METHOD}

This study was largely a qualitative in nature used a descriptive method, in which there is no treatment in this study, therefore, the data gathered from this study were not affected by others or by the researcher because in collecting the data, the researcher just attended the class and gather the data based on his capacity as a researcher.

The subject of the research was the lecture and second semester students of Non English Department. They are Pendidikan Agama Islam-A (PAI-A) students. The reason to choose this class is that it was class in where the students directly experiencing in the use of Herringbone technique. This class has 33 students, 17 girls and 16 boys. The setting of the research is in Universitas Wahab Hasbulloh (UNWAHA) which is located in Tambakberas Jombang.

The data of this research was the teacher and students' activities in applying the Herringbone technique in the process of teaching and learning reading comprehension in the classroom. The source of data was from the process of teaching and learning while the teacher implemented the Herringbone technique in the classroom. To collect the data appropriately, the researcher uses observation checklist and fieldnotes, interview, and questionnaires. The researcher analyze the students' work on herringbone diagram. The score put from the students' work on the second and the tast implementation of herringbone technique, because in the second meeting, the students start to answer the diagram alone. To analyze the data of the implementation of herringbone technique, the researcher uses data condensation, data display, and coclusion drawing or verification (Miles \& Huberman., 2014, p. 31).

\section{RESULT}

The observation was done on June $29^{\text {th }}, 2015$ until July $8^{\text {th }}, 2015$. The researcher accesses the subjects of the research namely a lecture and students in which they are involved in the teaching learning process, especially in the implementation of herringbone technique in the teaching reading narrative text at STAI-BU Tambakberas Jombang.

The objective of implementation of herringbone technique at STAI-BU Tambakberas Jombang is to show that students could understand the text. The 
fish diagram is used to help students identify the main idea and the related supporting ideas of a lesson, text or concept. It contains six questions that help students organize the details of the text. According to the lecture, the implementing herringbone makes the students to be more active and comprehend the story that they have red.

\section{A. The lecture's implementation of Herringbone technique in reading comprehension}

The implementation of herringbone technique in teaching reading was done by the lecture simultaneously in each teaching learning process from the first meeting until the fourth in a classroom. In implementing herringbone technique to teach reading, the lecture applied almost similar steps from the first meeting until the fourth, but the tittle of the text was different. The text was taken based on teaching material in reading book for second semester of PAI students.

\section{Phases of Herringbone technique}

Herringbone technique which was implemented in reading process was used to help in developing reading comprehension skill, especially in comprehending a narrative text. This technique emphasize on the process learning. The procedures of herringbone technique in reading narrative text can be presented using the following.

Figure 2:

Procedures of Herringbone technique adapted from Bouchard (2005, pp. 54-55)

Introduction

Select a text for students to read

\section{Showing the Herringbone Diagram to the Students}

- Draw a diagram of the herringbone

- Discuss the smaller bones are attached to the backbone of the fish

- Explain that they will be asked to look for information that

answers the following questions: who, what, when, where, how, and why 


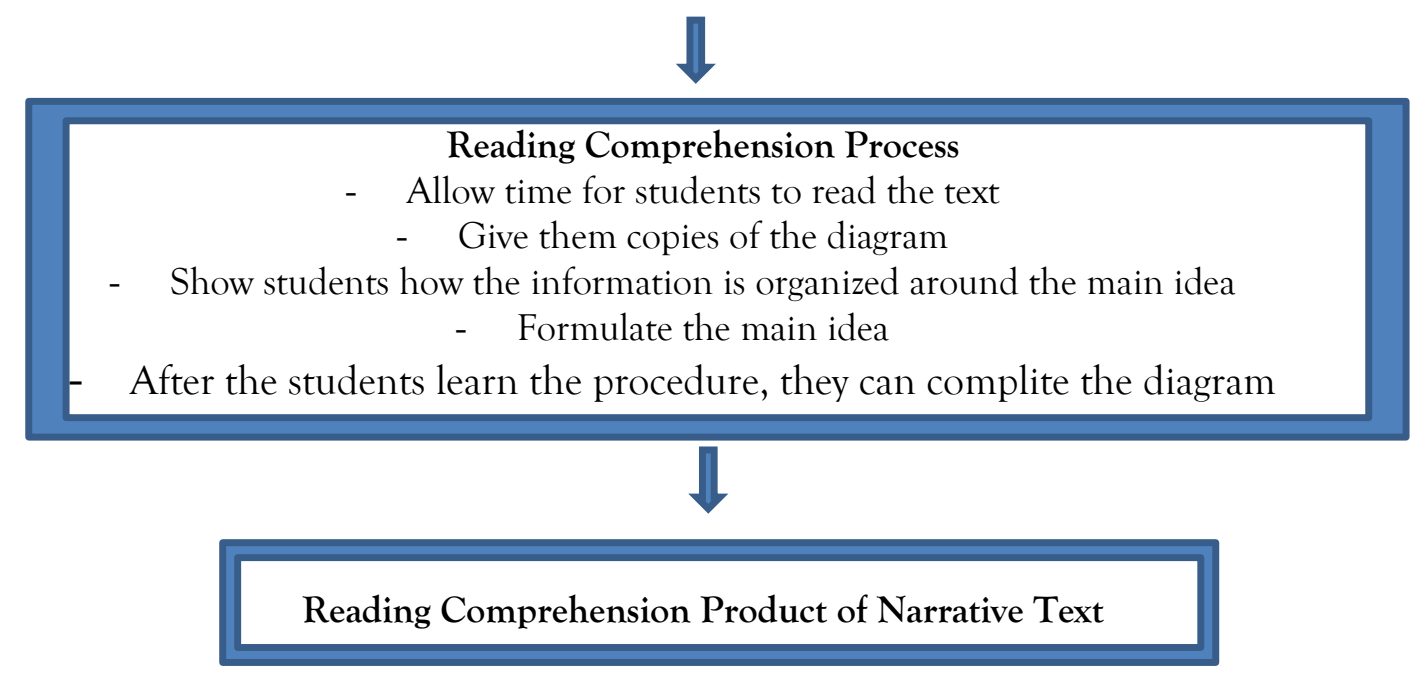

All of the figures above presents the process of Herringbone technique in the reading comprehension of narrative text. All the procedures do not only do in one meeting but several meetings, it is about four meetings. At the first until the fourth meeting, the lecture introduces herringbone technique and then gives some models of narrative text to be read and discuss about the comprehension of the text. In the following part, the students' and lecture' activities are described in detail.

The lecture applied the similar steps in implementing herringbone technique in each meeting as long as three times observation. The lecture then divided the learning activities in three sections namely pre activity, whilst activity, and post activity. From the observation of the implementation of herringbone technique that have been explained above in the selecting conversation of written field notes of every stages of the implementation, the researcher did data display which is suitable to the lecture ans students' activities related to the process approach stages. The data is displayed in table 1 as follows: 
72 Celt: A Journal of Culture, English Language Teaching \& Literature, Volume 18, Number 1, July 2018, pp. 64 - 78

Table 1:

Sorted data

\begin{tabular}{ll}
\hline All Sorted Data & Categorized Data \\
\hline L: I want to use herringbone technique & $\begin{array}{l}\text { How is the } \\
\text { for your reading process. Herringbone } \\
\text { technique itu adalah... }\end{array}$ \\
$\begin{array}{l}\text { technique } \\
\text { implemented by the } \\
\text { lecture in second } \\
\text { semester of PAI } \\
\text { students reading } \\
\text { comprehension? }\end{array}$ \\
$\begin{array}{l}\text { L: to make you more understand about } \\
\text { the technique, I will show you the } \\
\text { diagram of herringbone technique. }\end{array}$ \\
\hline
\end{tabular}

L: read the story at a glance on this page, read silently. Read the story, start from the title until the last paragraph.

Ss: Yes Mom..(students start to read the story)

L: I will call one student to read again, loudly, all of the story. Emm...mbak Intan!

Read the story loudly, please.

S1: yes mom.

Bismillahirrohmanirrohim....Mismatch...

(continuou to read the story)

L: ...please record the answer to the question on the herringbone diagram here and discuss with your group to formulate the main idea!

Ss : Yes mom

(students start to answer the six questions and discuss the main idea with their group)

L: based on your group, who is the text talking about?

Ss : Peter and Rhoda

L: What did Peter and Rhoda do?

Ss : They were eating in a restaurant

Ss : and talking about married and new

experience 
Rohmah, H., The Implementation of Herringbone Technique in Reading

Comprehension at Second Semester of Non-English Department

L: where did Jose saw a beautiful abstract

painting?

Ss : on the floor

$\mathrm{L}$ : when did Jose saw it?

S1: six o'clock in the evening, mom

$\mathrm{L}$ : How did they (Peter and Rhoda) test

the relationship?

S1: Peter and Rhoda try to make new friends

and have new experience

L : why did they do it?

S4: because peter and Rhoda very young

$\mathrm{L}$ : Could you tell me what is the main

idea of the first paragraph?

G1: Peter and rhoda eating in a restaurant

and talking about their relationship in the

future.

\section{Table of process and dispaly}

The table in the left side above was still a rough categorization of the obtained data from checklist and fieldtotes. However, in order to make the data above be much more systematical, the researcher gone to the next step to make it clear whether the data belong to the first or second quesstion.

Table 2 shows that generally the lecture implemented herringbone technique well. All the phases of herringbone technique done by the lecture, starting from Introducing Herringbone Technique to the students, Showing the Herringbone Diagram to the Students, reading the text, answer the herringbone diagram and discussion.

Table 2:

Table of data display

(How Herringbone technique is implemented by the lecture)

L: I want to use herringbone technique for your reading process. Herringbone

technique itu adalah.... 
74 Celt: A Journal of Culture, English Language Teaching \& Literature, Volume 18, Number 1, July 2018, pp. 64 - 78

L: to make you more understand about the technique, I will show you the diagram of herringbone technique.

L: read the story at a glance on this page, read silently. Read the story, start from the title until the last paragraph.

L: I will call one student to read again, loudly, all of the story. Emm...mbak Intan!

Read the story loudly, please.

L: ...please record the answer to the question on the herringbone diagram here and discuss with your group to formulate the main idea!

\begin{tabular}{ll}
\hline $\begin{array}{l}\text { L: based on your group, who is the text } \\
\text { talking about? }\end{array}$ & $\begin{array}{l}\text { Ss: Yes Mom..(students start to read } \\
\text { the story) }\end{array}$ \\
\hline L: What did Peter and Rhoda do? & $\begin{array}{l}\text { S1: yes mom. } \\
\text { Bismillahirrohmanirrohim...Mismatch. } \\
. .(\text { (continuou to read the story) }\end{array}$ \\
\hline
\end{tabular}

L: where did Jose saw a beautiful abstract Ss : Yes mom painting?

L : when did Jose saw it?

(students start to answer the six questions and discuss the main idea with their group)

L : How did they (Peter and Rhoda) test Ss : Peter and Rhoda the relationship?

L : why did they do it?

Ss : They were eating in a restaurant

Ss : and talking about married and new experience

L: Could you tell me what is the main Ss : on the floor idea of the first paragraph?

S1: six o'clock in the evening,mom

S1 : Peter and Rhoda try to make new friends and have new experience

S4: because peter and Rhoda very young

G1: Peter and rhoda eating in a restaurant and talking about their relationship in the future. 


\section{B. The students' results to the implementation of Herringbone technique in reading comprehension}

From the result of four times observation, the study found that when the lecture implemented herringbone technique in teaching reading comprehension, the students' responses and answers to the herringbone technique questions concerning general information of the text and main idea of a paragraph during teaching learning process increased. It can be seen from number of active students in responding Herringbone's questions improved in every meeting.

The first meeting showed that number of active student in responding herringbone's questions during teaching and learning process was low, there were only few active groups. In second meeting, number of active student was more than in the first meeting, eventhought they have to answer the herringbone questions individually. For the third and fourth, number of active student in responding the herringbone questions was more and more inreased.

The condition of class when the lecture taught reading in the last meeting, the students' replies to the herringbone questions were better than the first meeting, second, and the third. The number of active students was increase.

Every time the the lecture read the question on the diagram, certainly the students answered well and fluently, it can be detected from conversation in the extract above, like some students (SS), all students(Ss), and many students (MS) answered in the extract. It showed that total student's reply in the fourth meeting more than three meetings before. It means that the students' result in reading comprehension and students' responses to the reading comprehension questions concerning general information of the text and main idea of a paragraph through the implementation of herringbone technique increased.

C. Students' respond to the implementation of the Herringbone technique in reading comprehension class

The students' responses are obtained from students' behavior while they are in the teaching and learning process as well as being interviewed. Moreover, the researcher took five samples of students. Furthermore, the result of observation and interview is divided into three parts, the sudents' interest of the HT in English lesson, the effect of the game in learning and 
comprehension and the last was the benefit of the HT in students' reading comprehension.

From the interview about the application of the Herringbone Technique in English lesson, most of the students like the applied of herringbone technique in teaching and learning English. the herringbone technique made them more interested in learning English.The herringbone technique is simple and interesting technique. It did not need many tools to do this technique, except herringbone diagram. It was easier to do. From the observation sheet in first until the last implementation, the students felt that by using herringbone technique was more interesting and easier.

From the researcher's interview to the students about the benefit of herringbone technique in students' reading comprehension, it that was shown that the herringbone technique gave positive effect for the students in their reading comprehension. Learning by using herringbone technique helped students more easily in understanding the text, so that, the students were more easily to answer questiions related with the text.

And from the effect of the herringbone technique in learning reading comprehension, the students agree that the use of herringbone technique could help the students in increasing the study achievement in English lesson. It proved when they haven't apply the herringbone technique, the students felt difficult to make the main idea of the text. But, after applying the herringbone technique, they felt happy and helped because before make the main idea, they have to answer the six questions which have correlation with the main idea.

To sum the respond up, based on the finding of the interview result it can be concluded that the applied of herringbone technique in teaching reading comprehension made the students more interest in studying English. The diagram also helped the students easier in learning English so that the students could answer questions and the main idea related with the text properly because their reading comprehension was better than before.

\section{CONCLUSION}

The present study has investigated a number of issues as presented in the discussion including the techniques of teaching used by the teacher in using herringbone technique. The lecture believes in the use of herringbone in 
reading comprehension of non-English department, then the findings of the research, as a set of conclusions, are inferred as follows.

Based on the findings and discussion of the study, it can be cocluded that first, the lecture can implement herringbone technique in teaching reading comprehension well, since the steps applied by the lecture in implementing this technique is similar to the steps suggested by promonents of herringbone technique.

The lecture's activity in observing phase was done properly. She presented pictures, a text, and picture of herringbone diagram. She also explained how to answer six questions an manage the main idea in the diagram. The activities were reading text, listening to the lecture's explanation, filling the fishbone diagram, and doing discussion.

Second, this study also found that students' reading comprehension increase after herringbone technique was implemented, it can be seen from the student's responses result to the herringbone questions and the number of main ideas during teaching learning process increase from first meeting to next meeting up to fourth meeting. The students' respond to the implementation of herringbone technique was very good. It can be seen from the data interview. Most of the students like the applied of herringbone technique in teaching and learning English.

The herringbone technique gave positive effect for the students in their reading comprehension. Learning by using herringbone technique helped students more easily in understanding the text, so that, the students were more easily to answer questions related with the text. The technique also make students enjoy to learn English, especially in reading comprehension.

\section{REFERENCES}

Bouchard, M. (2005). Comprehension Strategies for English Language Learners. New York: Scholastic Inc.

Deegan, J. (2006). Herringbone Technique. Teacher Web. Retrieved on March 14, 2013 from http://www.teacherweb.com/PA/Nazareth AreaMiddleSchool/TheSpecialistTeam/HerringboneTechnique.doc

Miles, M. B., \& Huberman, A. M. (1994). Qualitative data analysis: An expanded sourcebook. New York: SAGE. 
78 Celt: A Journal of Culture, English Language Teaching \& Literature, Volume 18, Number 1, July 2018, pp. 64 - 78

Nuttall, C. (1996). Teaching reading skills in a foreign language. Bath: Heinemann.

Nunan, D. (Ed.). (1992). Collaborative language learning and teaching. Cambridge University Press.

Richards, J. C., \& Renandya, W. A. (Eds.). (2002). Methodology in language teaching: An anthology of current practice. Cambridge University Press.

Snow, C. (2002). Reading for Understanding. Towards an REDD Program in Reading Comprehension. Santa Monica: RAND Corporation.

Tierney, R. J., Readence, J. E., \& Dishner, E. K. (1980). Reading strategies and practices: A guide for improving instruction. Boston: Allyn \& Bacon. 